Crop Breeding and Applied Biotechnology 13: 75-82, 2013

Brazilian Society of Plant Breeding. Printed in Brazil

\title{
ARTICLE
}

\section{Resistance to Asian soybean rust in soybean lines with the pyramided three $R p p$ genes}

Naoki Yamanaka ${ }^{1 *}$, Noelle G Lemos ${ }^{1}$, Miori Uno ${ }^{2}$, Hajime Akamatsu ${ }^{1}$, Yuichi Yamaoka ${ }^{3}$, Ricardo V Abdelnoor ${ }^{4}$, Alessandro L e Braccini ${ }^{5}$ and Kazuhiro Suenaga ${ }^{1}$

Received 26 August 2012

Accepted 12 December 2012

\begin{abstract}
In this study, the influence of genetic background on the resistance level of a soybean line carrying Rpp2, Rpp4, and Rpp5 was evaluated by backcrossing it with a susceptible variety. It was also evaluated eight lines which carry these Rpp genes against five Asian soybean rust (ASR) isolates, in order to determine the likely range of resistance against ASR isolates differing in pathogenicity. The results indicated that a high level of resistance against various ASR isolates could be retained in lines carrying the three Rpp genes in susceptible genetic backgrounds, although minor influences of plant genetic background and ASR pathogenicity to the ASR resistance could occur. Thus, lines with the pyramided three Rpp genes should be effective against a complex pathogen population consisting of diverse Phakopsora pachyrhizi isolates.
\end{abstract}

Key words: Backcross breeding, gene pyramiding, marker-assisted selection, pathogenic diversity.

\section{INTRODUCTION}

The fungus Phakopsora pachyrhizi, the causal agent of Asian soybean rust (ASR), is an airborne foliar disease considered to be one of the most serious economic threats for soybean producers (Goellner et al. 2010). ASR was first detected in the American Continent, in Paraguay, in May 2001 (Yorinori et al. 2005), and has caused severe losses of soybean production in South America (Yorinori 2008). Management strategies such as the use of fungicides, the adoption of a free host period, and the use of genetic resistance are important for controlling ASR (Yorinori 2008). The development of soybean varieties resistant to ASR is considered the most economical control strategy; therefore it is important to facilitate its management (Twizeyimana et al. 2007, Arias et al. 2008, Pierozzi et al. 2008). However, resistance is not always durable due to pathogen variability (Oliveira et al. 2005), and there is a large regional pathogenic diversity in the ASR pathogen population in Brazil (Freire et al. 2008, Kato and Yorinori 2008, Soares et al. 2009, Akamatsu et al. 2013).
In soybean, the pyramiding of resistance genes is known for its high and broad-spectrum resistance to soybean mosaic virus (Saghai Maroof et al. 2008). The pyramiding of available ASR resistance genes in a single soybean cultivar may also provide more durable resistance against $P$. pachyrhizi populations expressing a wide range of pathogenicity in the field (Arias et al. 2008). Six resistance loci (Rpp: resistance to P. pachyrhizi, Rpp1-6) have been mapped with molecular markers for ASR (Hyten et al. 2007, Silva et al. 2008, Garcia et al. 2008, Chakraborty et al. 2009, Ray et al. 2009, Monteros et al. 2010, Li et al. 2012); thus it can be tagged and pyramided using molecular markers (Yamanaka et al. 2008, Lemos et al. 2011).

In a previous study (Lemos et al. 2011), it was identified the different genetic contributions of three resistance loci, $R p p 2$, Rpp4, and Rpp5, to the resistance against a highly virulent Brazilian ASR population. It was also observed high resistance in the line carrying these three resistance genes. However, high ASR resistance was detected only in a single three-Rpp-pyramided line against one ASR popula-

\footnotetext{
1 Japan International Research Center for Agricultural Sciences (JIRCAS), 1-1 Ohwashi, Tsukuba, Ibaraki, 305-8686, Japan. *E-mail: naokiy@affrc.go.jp

2 Fundacion Nikkei-Cetapar, Ruta 7, Km 45, Distrito Yguazu, Departamento de Alto Parana, Paraguay

${ }^{3}$ University of Tsukuba, Faculty of Life and Environmental Sciences, 1-1-1 Tennodai, Tsukuba, Ibaraki, 305-8572, Japan

${ }^{4}$ Embrapa-Soja, CP 231, 86.001-970, Londrina, PR, Brazil

5 Universidade Estadual de Maringá (UEM), Colombo Avenue 5790, 87.020-900, Maringá, PR, Brazil
} 
tion. The objective of this study was to investigate the ASR resistance of soybean lines pyramided with $R p p 2, R p p 4$, and Rpp 5 using genotypes with different genetic backgrounds and ASR isolates with different virulences.

\section{MATERIALS AND METHODS}

\section{Plant materials and marker-assisted selection}

Two kinds of experiments were carried out for evaluating Rpp-pyramided lines in this study. For the first experiment, a $\mathrm{BC}_{1} \mathrm{~F}_{1}$ plant was generated by two-time backcrosses using the line, 'No6-12 $\mathrm{F}_{3}-1$ ' (Lemos et al. 2011) as a donor parent and the susceptible Paraguayan variety 'Aurora' as a recurrent parent (Figure 1). Markerassisted selection (MAS) was applied to obtain one $\mathrm{BC}_{1} \mathrm{~F}_{1}$ plant and two $\mathrm{BC}_{1} \mathrm{~F}_{2}$ plants (' $\mathrm{BC}_{1} \mathrm{~F}_{2}$ 6-27' and ' $\mathrm{BC}_{1} \mathrm{~F}_{2}$ 6-90') carrying all of three resistance genes Rpp2, Rpp4, and Rpp 5 as heterozygous and homozygous, respectively. DNA marker analysis was performed following a previous report (Lemos et al. 2011). Five $\mathrm{BC}_{1} \mathrm{~F}_{3}$ plants were used for the first experiment along with three plants of both No6- $12 \mathrm{~F}_{3}-1$ and Aurora.

In a previous study (Lemos et al. 2011), it was obtained a total of eight $\mathrm{F}_{3}$ lines $\left(\mathrm{No} 2-4 \mathrm{~F}_{3}-3\right.$, No2 $-4 \mathrm{~F}_{3}-22, \mathrm{No}_{2}-4 \mathrm{~F}_{3}-25$,
No2- $4 \mathrm{~F}_{3}-28$, No2-4F -33 , No6- $12 \mathrm{~F}_{3}-1$, No6- $12 \mathrm{~F}_{3}-2$, and No6-12F 3 -7) carrying Rpp2, Rpp4, and Rpp 5 as homozygous resistant (Figure 1). In the second experiment, it was used three $\mathrm{F}_{4}$ plants derived from each of the eight lines, in order to evaluate ASR resistance. Three plants of both parents of the $\mathrm{F}_{2}$ population: 'An76-1' (Rpp2 and Rpp4) and 'Kinoshita' (Rpp5), and of the ancestors of An76-1: 'PI230970' (Rpp2), 'PI459025' (Rpp4), and 'BRS184' (susceptible) were also used for the second experiment (Figure 1). For the second experiment, single-lesion isolation was carried out to obtain ASR isolates with different virulences from one another. A susceptible Brazilian variety, BRS184, and a susceptible Japanese variety, 'Tachinagaha', were used for single-lesion isolation from the Brazilian and Japanese ASR populations, respectively. Fourteen differential varieties (Yamaoka et al. 2002, Kato and Yorinori 2008, Yamanaka et al. 2010, Akamatsu et al. 2013) (Table 1) were used for virulence characterization of the obtained ASR isolates.

\section{Single-lesion isolation and virulence evaluation}

Purification of the two ASR populations BRP-2 and JRP (Yamanaka et al. 2010) by single-lesion isolation was carried out using a detached-leaf method. Healthy mature leaves of susceptible varieties were excised from plants

\section{Plant materials for the experiment 1}

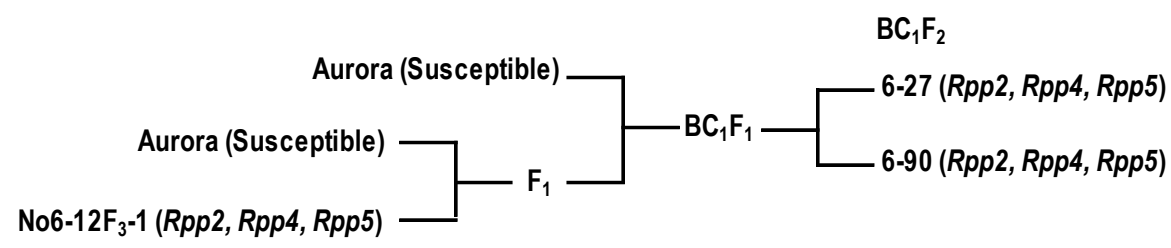

Plant materials for the experiment 2

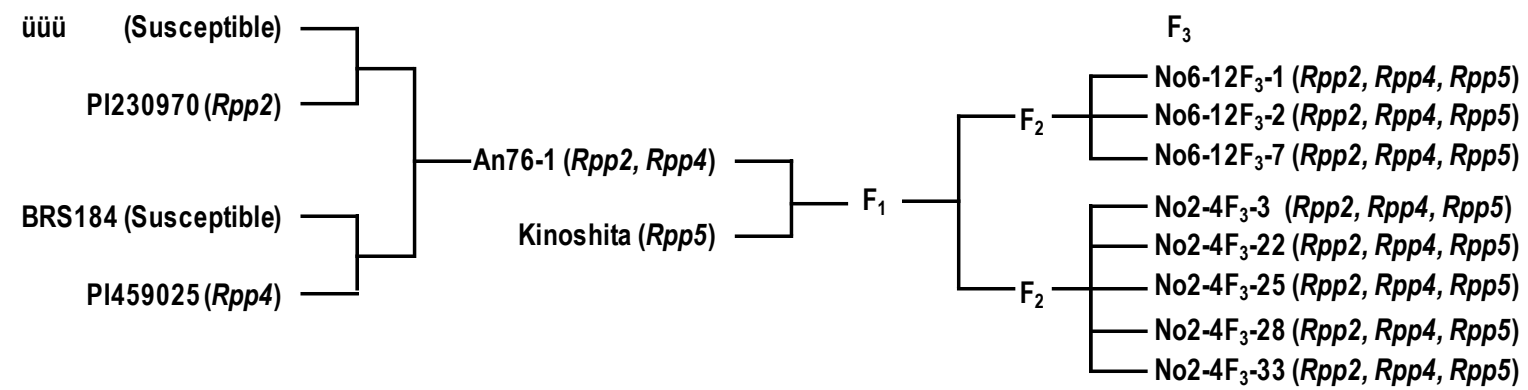

Figure 1. Pedigrees of soybean genotypes used for two kinds of experiments in this study. The resistant $R p p$ alleles that each genotype carries in homozygous state are indicated in parentheses. For each cross, the ovule parent is shown above the pollen parent. 
Table 1. Virulence of four Brazilian and one Japanese ASR isolates in 14 differential varieties as determined by leaf culture experiment

\begin{tabular}{|c|c|c|c|c|c|c|c|c|c|c|c|c|c|c|}
\hline & \multicolumn{14}{|c|}{ Infection types on differential varieties ${ }^{1}$} \\
\hline \multicolumn{15}{|c|}{ Brazilian isolates } \\
\hline BRP-2.5 & $\mathrm{S}$ & $\mathrm{S}$ & $\mathrm{S}$ & $\mathrm{S}$ & $\mathrm{S}$ & $\mathrm{S}$ & $\mathrm{S}$ & $\mathrm{R}$ & $\mathrm{S}$ & $\mathrm{S}$ & $\mathrm{S}$ & $\mathrm{S}$ & $\mathrm{S}$ & $\mathrm{S}$ \\
\hline BRP-2.6 & $\mathrm{S}$ & $\mathrm{S}$ & I & $\mathrm{S}$ & $\mathrm{S}$ & $\mathrm{S}$ & $\mathrm{S}$ & S & SR & $\mathrm{S}$ & I & S & S & $\mathrm{S}$ \\
\hline BRP-2.49 & $\mathrm{S}$ & $\mathrm{S}$ & HR & $\mathrm{S}$ & $\mathrm{S}$ & $\mathrm{S}$ & $\mathrm{S}$ & $\mathrm{R}$ & $\mathrm{S}$ & S & HR & $\mathrm{S}$ & $\mathrm{S}$ & $\mathrm{S}$ \\
\hline$(\mathrm{BRP}-2)^{2}$ & S & $\mathrm{S}$ & S & $\mathrm{S}$ & $\mathrm{S}$ & $\mathrm{S}$ & SR & SR & SR & SR & $\operatorname{mix}$ & $\mathrm{S}$ & $\mathrm{S}$ & - \\
\hline
\end{tabular}

grown in an ASR-free growth chamber. The lower surfaces of leaves were washed with distilled water and rubbed with fingers. After removing the excess water on the leaves, they were placed in plastic Petri plates with the abaxial surface exposed. Cleaning wipes (Kimberly-Clark Corporation) were placed to sandwich the bottom of each leaf and moistened with sterile distilled water. A spore suspension $(100,000$ spores $\left.\mathrm{mL}^{-1}\right)$ containing urediniospores and $0.04 \%$ Tween 20 (Sigma) was prepared as an inoculum, placed on a $5 \mathrm{~mm}$ piece of filter paper (ca. 5-mm width), and spread on the leaves. The Petri plates containing the inoculated leaves were closed with the lids and maintained in a growth chamber at $21^{\circ} \mathrm{C}$ for $12 \mathrm{~h}$ in the dark and then incubated in a growth chamber at $21{ }^{\circ} \mathrm{C}$ under a 12 -h light photoperiod. Luminance at the plate surface of the chamber was approximately 3,000 lux provided by fluorescent lamps. Single-lesion candidates were cut out along with the surrounding leaf area (ca. 1 $\mathrm{cm}^{2}$ ) under a stereomicroscope and placed on water-soaked filter papers in individual Petri plates. When urediniospores were developed on the single lesion, the leaf pieces with sporulating lesions were transferred to individual $2.0 \mathrm{~mL}$ microtubes and stored at $-80{ }^{\circ} \mathrm{C}$. For multiplying spores of the single lesion isolates, $0.04 \%$ Tween 20 solution was added to a $2.0 \mathrm{~mL}$ microtube containing a sporulating single lesion, and the resulting spore suspension was applied to detached leaves. After incubation for 2-3 weeks, newly reproducing spores were harvested from the infected leaves and stored at $-80^{\circ} \mathrm{C}$, or used for further experiments. The spore multiplication process was repeated to prepare enough spores for inoculation in the subsequent experiments.
A set of 14 soybean differential varieties (Table 1) was grown in an ASR-free growth chamber for evaluating the pathogenicity of the ASR isolates. Three weeks after sowing, healthy mature leaves were excised and used for inoculation. Inoculation of the detached leaves was carried out with 100 $\mu \mathrm{L}$ of 50,000 spores $\mathrm{mL}^{-1}$ spore suspension containing $0.04 \%$ Tween 20 solution. Three resistance characters were scored for 30 lesions 14 days after inoculation: frequency of lesions with uredinia (\%LU), number of uredinia per lesion (NoU), and sporulation level (SL). Three independent experiments were carried out to obtain the average of three replicates. In the present study, the threshold values distinguishing resistant $(\mathrm{R})$ and susceptible $(\mathrm{S})$ reactions for these three characters were redefined for the detached leaf method (Table 2). The phenotypes of the differential varieties were then subclassified into five categories: susceptible, slightly resistant, resistant, highly resistant, and immune (Table 2) according to the $\mathrm{R}$ or $\mathrm{S}$ phenotypes for the three characters following a previous study (Yamanaka et al. 2011).

\section{Evaluation of three $R p p$-pyramided lines for ASR resistance}

In the first experiment, the two $\mathrm{BC}_{1} \mathrm{~F}_{3}$ families were evaluated for ASR resistance together with No6-12 $\mathrm{F}_{3}-1$ and Aurora. Three weeks after sowing, plants grown in the growth chamber were inoculated with a Brazilian ASR population, BRP-2 used in the previous studies (Yamanaka et al. 2010, Lemos et al. 2011, Yamanaka et al. 2011, Akamatsu et al. 2013). The three resistance characters \%LU, NoU, and SL were evaluated for the first experiment. 
N Yamanaka et al.

Table 2. Classification of three resistance characters: frequency of lesions with uredinia (\%LU), number of uredinia per lesion (NoU), and sporulation level (SL) and criteria to determine resistance of differential varieties for the detached leaf method

\begin{tabular}{lcr}
\hline \multirow{2}{*}{ Resistance characters } & \multicolumn{2}{c}{ Phenotypic values } \\
\cline { 2 - 3 } & Resistant (R) & Susceptible (S) \\
\hline \%LU & $0.0 \leq \mathrm{x}<80.0$ & $80.0 \leq \mathrm{x} \leq 100.0$ \\
NoU & $0.0 \leq \mathrm{x}<1.2$ & $1.2 \leq \mathrm{x}$ \\
SL & $0.0 \leq \mathrm{x}<1.5$ & $1.5 \leq \mathrm{x} \leq 3.0$ \\
\hline
\end{tabular}

\begin{tabular}{ll}
\hline Resistance categories & Criteria $^{1}$ \\
\hline Immune & No lesion formed \\
Highly resistant & Lesions formed but no uredinia formed \\
Resistant & Resistant phenotypes observed in all three resistance characters \\
Slightly resistant & Resistant phenotypes observed in any of three resistance characters \\
Susceptible & Susceptible phenotypes observed in all three resistance characters \\
\hline
\end{tabular}

${ }^{1}$ This classification criterion of varieties is same as a previous study (Yamanaka et al. 2011).

In the second experiment, eight Rpp-pyramided lines were evaluated together with the five ancestors for resistance to five different ASR isolates. Soybean plants were grown in a growth chamber and inoculated with the four Brazilian ASR isolates (BRP-2.1, BRP-2.5, BRP-2.6 and BRP-2.49) and the Japanese isolate (T1-2) three weeks after sowing. Four resistance characters were evaluated: \%LU, NoU, SL, and incubation period (IP: the number of days from inoculation to the appearance of visible symptoms).

Growth, inoculation, and evaluation conditions in both experiments were mentioned in previous studies (Soares et al. 2009, Yamanaka et al. 2010, Lemos et al. 2011, Yamanaka et al. 2011). Moreover, t-test was applied to determine significances of the differences between the Rpp-pyramided lines and their ancestors on the values of \%LU, NoU, SL, or IP.

\section{RESULTS AND DISCUSSION}

In a previous study (Lemos et al. 2011), the Rpp-pyramided line No6-12F -1 (Rpp2, Rpp4, and Rpp5) showed very low $\mathrm{NoU}(0.1), \% \mathrm{LU}(7.7 \%)$, and $\mathrm{SL}(0.0)$ against the highly virulent Brazilian ASR population BRP-2. In the first experiment using the same ASR population, it was observed a similar high resistance in No6-12 $\mathrm{F}_{3}-1$ with very low $\mathrm{NoU}$ (0.1), \%LU (6.7\%), and SL (0.1), but a little sporulation (SL $=0.1)$ (Figure 2). This SL value is equivalent to one lesion with a minimal level of sporulation $(\mathrm{SL}=1$, Yamanaka et al. 2010) in every 10 lesions. A similar high level of resistance to BRP-2 was also observed in the two $\mathrm{BC}_{1} \mathrm{~F}_{3}$ families, 6-27 and 6-90. In contrast, the recurrent parent Aurora showed typical susceptible lesions and significant high values for these three characters (Figure 2). Each $\mathrm{BC}_{1} \mathrm{~F}_{3}$ family was derived from two backcrosses with Aurora; thus, it was expected to carry $75 \%$ of the Aurora genome. Accordingly, the resistance effect of pyramiding Rpp2, Rpp4, and Rpp5 can be expected not only in the No6- $12 \mathrm{~F}_{3}-1$ genetic background, but also in Aurora, the susceptible parent.

For the second experiment, a total of five ASR isolates were obtained to evaluate the effect of pyramiding $R p p 2$, $R p p 4$, and Rpp 5 on resistance against ASR isolates that present different pathogenicities. Although some differences in virulence among the four Brazilian ASR isolates were observed in the differential varieties (PI587880A (Rpp1), PI459025 (Rpp4), Shiranui (Rpp5), and PI587905 (unknown)), there was no large difference in virulence between the five ASR isolates or their two sources BRP-2 and JRP (Table 1). Thus, the four Brazilian ASR isolates (BRP-2.1, BRP-2.5, BRP-2.6, and BRP-2.49) and one Japanese ASR isolate (T1-2) differed in virulence, whereas the four Brazilian isolates displayed higher virulence than the Japanese (Table 1), in accordance with the observations of a previous studies (Yamanaka et al. 2010, Yamanaka et al. 2011). In addition, the Brazilian isolates were more virulent than most of the ASR populations previously obtained from Brazil (Kato and Yorinori 2008, Soares et al. 2009, Akamatsu et al. 2013). Accordingly, soybean lines which present high resistance to these Brazilian ASR isolates can be expected to be good breeding material for ASR resistance in Brazil.

In a second experiment, $\% \mathrm{LU}, \mathrm{NoU}$, and SL were lower $(\mathrm{P}<0.05)$ in the $R p p$-pyramided lines $(R p p 2+R p p 4+R p p 5)$ than those found in their five ancestors: An76-1 (Rpp2+Rpp4), Kinoshita (Rpp5), PI230970 (Rpp2), PI459025 (Rpp4), and BRS184, except for Kinoshita, with T1-2 infection, 
(A)
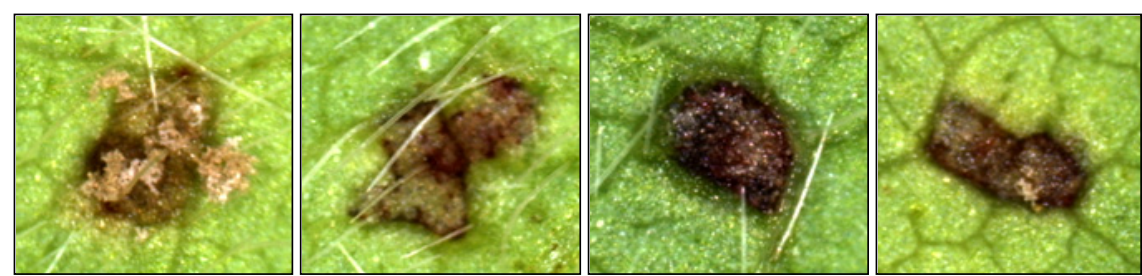

Aurora

No6-12F ${ }_{3}-1$

$\mathrm{BC}_{1} \mathrm{~F}_{3} 6-27$

$\mathrm{BC}_{1} \mathrm{~F}_{3} 6-90$

(B)

(NoU, SL)

(\%LU)

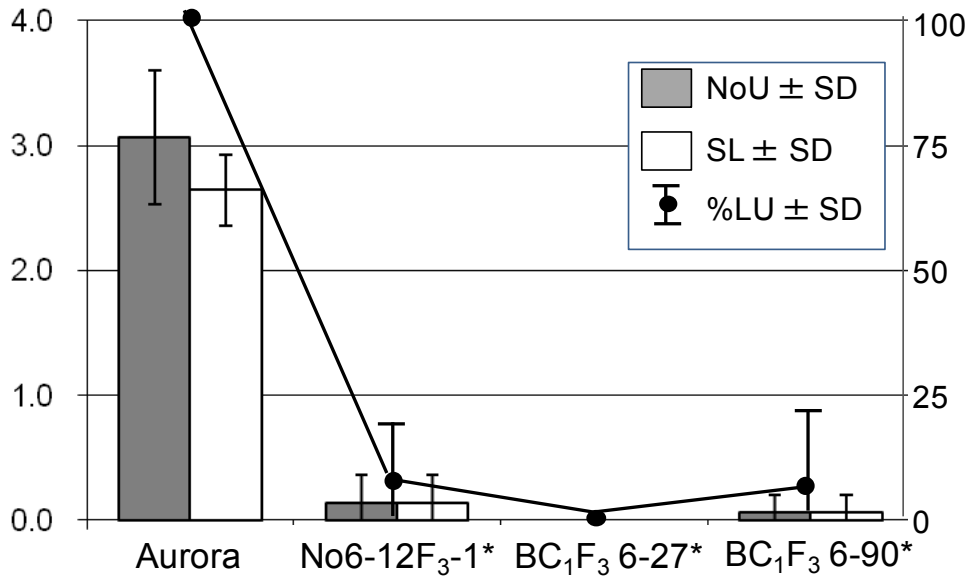

Figure 2. Images of the ASR lesions (A) and frequency distributions of \%LU: frequency of lesions with uredinia, NoU: number of uredinia per lesion, and SL: sporulation level with standard deviations (SD) (B) against the Brazilian ASR population BRP-2 in two $\mathrm{BC}_{1} \mathrm{~F}_{3}$ families carrying three resistance genes (Rpp2, Rpp4, and Rpp5), the recurrent parent: Aurora (susceptible), and the donor parent: No6-12F -1 (Rpp 2 , Rpp4, and $R p p 5)$. The asterisks mean they do not differ significantly $(\mathrm{P}>0.05)$ in all three characters.

and for An76-1, with BRP-2.49 infection, in which typical resistant lesions were observed (Table 3). The levels of \%LU, NoU, and SL in the eight Rpp-pyramided lines were different among the five ASR isolates. However, this difference was not significant at $\mathrm{P}<0.05$ even though the five isolates displayed different virulences. These results indicated that Rpp-pyramided lines have significantly higher and relatively more stable resistance against different ASR isolates than their ancestors. In contrast, average of IP in the Rpp-pyramided lines infected by T1-2 (6.1 days) and BRP-2.6 (4.3 days) were significantly different than the averages for other infections: BRP-2.1 (3.2 days), BRP-2.5 (3.1 days), and BRP-2.49 (3.3 days). Thus, IP in $R p p$-pyramided lines was relatively unstable against ASR virulence compared to the resistance expressed as lesion characteristics (\%LU, NoU, and SL).

Although Rpp-pyramided lines had higher and more stable resistance than their ancestors against different ASR virulences, significant differences in the resistance characters were detected among Rpp-pyramided lines. For example, No6- $12 \mathrm{~F}_{3}-7$ displayed a very low SL value (0.0), for all 5 isolates, but No2-4F -25 showed relatively high SL values: 0.2 for BRP-2.1 infection, 0.0 for BRP-2.5, 0.9 for BRP-2.6, 0.4 for BRP-2.49, and 0.0 for T1-2 among $R p p$-pyramided lines (Table 3 ). The Rpp-pyramided lines tested in this study were derived from the same $\mathrm{F}_{2}$ population, but from different $\mathrm{F}_{2}$ or $\mathrm{F}_{3}$ plants. The difference in resistance levels observed among the three Rpp-pyramided lines could be derived from the genetic background apart from the three resistance genes. It may accordingly be concluded that high resistance can be expected in different genetic backgrounds, as in the first experiment; however the level of resistance could vary according to the genetic background of the breeding materials.

No significant difference in IP against the four Brazilian isolates was detected between Rpp-pyramided lines and the ancestors. This result supported previous observations that these three Rpp genes do not contribute to enhancing IP against Brazilian ASR populations (Yamanaka et al. 2008, Lemos et al. 2011). Zambenedetti et al. (2007) also observed 
N Yamanaka et al.

Table 3. Mean values of \%LU: frequency of lesions with uredinia, NoU: number of uredinia per lesion, and SL: sporulation level, and IP: incubation period against five ASR isolates (BRP-2.1 T1-2) in eight lines carrying the three resistance genes Rpp2, Rpp 4, and Rpp5 and its five ancestors

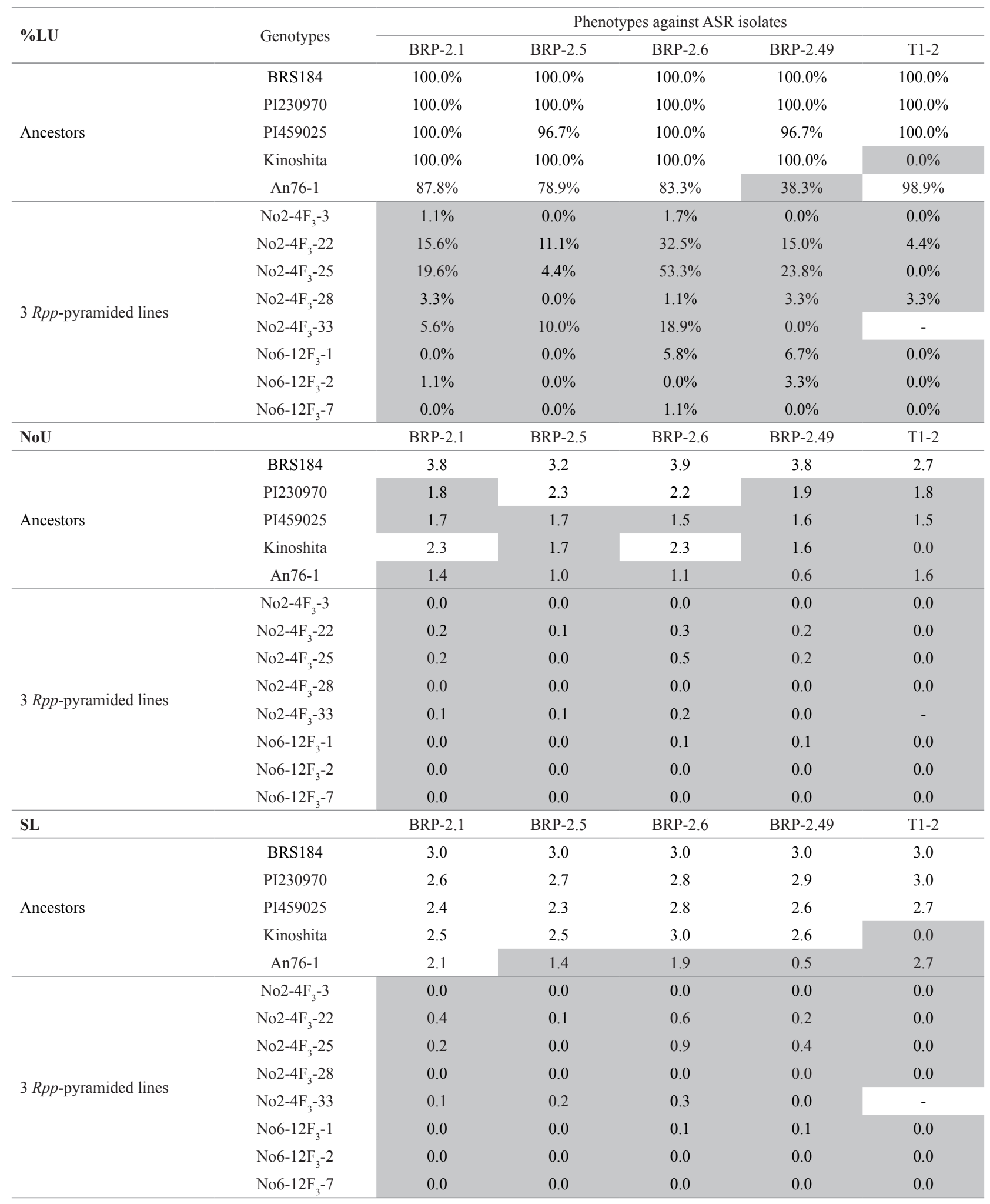

To be continued... 
Resistance to Asian soybean rust in soybean lines with the pyramided three Rpp genes

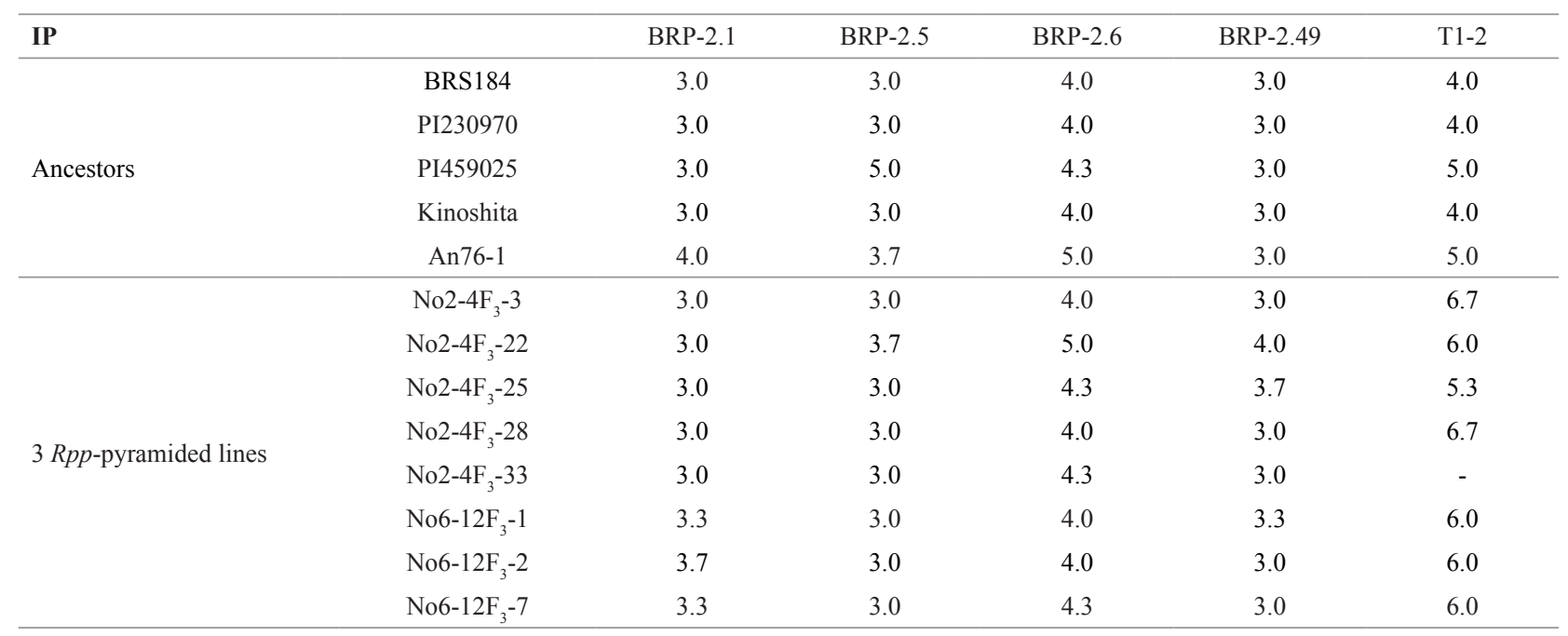

Classification in terms of resistant (shading) or susceptible phenotypes in the resistance characters: \%LU, NoU, and SL were determined according to a previous study (Yamanaka et al. 2011). -: The data is missing. Resistance or susceptible classification was not applied for IP.

no difference in IP between susceptible and resistant varieties. However, for T1-2 infection, a significantly longer (1.7 days) IP of the three-Rpp-pyramided lines was observed in comparison with their ancestors (Table 3). Thus, Brazilian ASR isolates not only were more virulent (Table 1), but they also formed lesions faster than Japanese ASR isolate. Although this slower formation of T1-2 lesions may make it possible to detect the relatively late lesion development (longer IP) in the three-Rpp-pyramided lines, the resistance carried by these lines could contribute to delaying lesion development, depending on the ASR isolate.

This study proposes that the $R p p$-pyramided lines carrying Rpp2, Rpp4, and Rpp5 are promising breeding material for ASR resistance based on their high and relatively stable resistance to all tested ASR inocula and in all genetic backgrounds tested in this research. However, minor differences in resistance depending on the genetic background of the breeding material and the virulence of the ASR isolate were also detected. Accordingly, besides developing Rpp-pyramided cultivars in several different genetic backgrounds, it is also necessary to evaluate the performance of other Rpp-pyramided lines that carry multiple $R p p$ genes combinations different from Rpp2, Rpp4, and $R p p 5$, in order to identify more useful $R p p$-pyramided lines that show lower variation of resistance against divergent ASR pathogen in Brazil.

\section{ACKNOWLEDGEMENTS}

We thank Ms. Akiko Takahashi, Sachiko Nishimura, Yukie Muraki, Tomomi Mori, and Mio Morishita (JIRCAS); Mr. Iwao Ohyama, Fabio Centurion, Sergio Mitsui, and Toshiyuki Horita (Nikkei-Cetapar); and Dr. Michitaka Komeichi (Cooperativa Iguazu Agricola Ltda.) for their technical assistance, advice, and encouragement. The authors would like to thank Enago (www.enago.jp) for the English language review. This study was supported by the JIRCAS research projects "Identification of Stable Resistance to Soybean Rust for South America" and "Development of Breeding Technologies toward Improved Production and Stable Supply of Upland Crops".

\section{Resistência à ferrugem asiática em linhagens de soja com três genes $R p p$ de resistência}

Resumo - Neste estudo, foi avaliada a influência da composição genética no nível de resistência de uma linhagem de soja com genes Rpp2, Rpp4 e Rpp5, gerada através de retrocruzamentos com um cultivar suscetivel. Também foram avaliadas oito linhagens carregando esses genes Rpp contra cinco isolados de ferrugem asiática da soja (FAS) para determinar a provável faixa de resistência contra isolados que diferem em patogenicidade. Os resultados indicam que um alto nível de resistência pode ser obtido em linhagens contendo os três genes Rpp inseridos em base genética suscetível, embora pequenas influências da base genética e da patogenicidade da FAS na resistência à ferrugem possam também ocorrer. Assim, linhagens com os genes Rpp2, Rpp 4 e Rpp5 piramidados devem ser efetivas contra uma população complexa que consiste de vários isolados de Phakopsora pachyrhizi.

Palavras-chave: Melhoramento por retrocruzamento, piramidação de genes, seleção assistida por marcadores, diversidade patogênica. 


\section{REFERENCES}

Akamatsu H, Yamanaka N, Yamaoka Y, Soares RM, Morel W, Ivancovich AJG, Bogado AN, Kato M, Yorinori JT and Suenaga K (2013) Pathogenic diversity of soybean rust in Argentina, Brazil, and Paraguay. Journal of General Plant Pathology 79: 28-40.

Arias CAA, Toledo JFF, Almeida LA, Pipolo AE, Carneiro GES, Abdelnoor RV, Rachid BF and Ribeiro AS (2008) Asian rust in Brazil: Varietal resistance. In Kudo H, Suenaga K, Soares RM and Toledo A (eds.) Facing the challenge of soybean rust in South America. JIRCAS, Tsukuba, p. 29-30 (JIRCAS working report no. 58).

Chakraborty N, Curley J, Frederick RD, Hyten DL, Nelson RL, Hartman GL and Diers BW (2009) Mapping and confirmation of a new allele at Rppl from soybean PI 594538A conferring RB lesion-type resistance to soybean rust. Crop Science 49: 783-790.

Freire MCM, Oliveira LO, Almeida AMR, Schuster I, Moreira MA, Liebenberg MM and Mienie CMS (2008) Evolutionary history of Phakopsora pachyrhizi (the Asian soybean rust) in Brazil based on nucleotide sequences of the internal transcribed spacer region of the nuclear ribosomal DNA. Genetics and Molecular Biology 31: 920-931.

Garcia A, Calvo ES, Kiihl RAS, Harada A, Hiromoto DM and Vieira LGE (2008) Molecular mapping of soybean rust (Phakopsora pachyrhizi) resistance genes: discovery of a novel locus and alleles. Theoretical and Applied Genetics 117: 545-553.

Goellner K, Loehrer M, Langenbach C, Conrath U, Koch E and Schaffrath U (2010) Phakopsora pachyrhizi, the causal agent of Asian soybean rust. Molecular Plant Pathology 11: 169-177.

Hyten DL, Hartman GL, Nelson RL, Frederick RD, Concibido VC, Narvel JM and Gregan PB (2007) Map location of the Rpp1 locus that confers resistance to soybean rust in soybean. Crop Science 47: 835-838.

Kato M and Yorinori JT (2008) A study on a race composition of Phakopsora pachyrhizi in Brazil: a difficulty of race identification. In Kudo H, Suenaga K, Soares RM and Toledo A (eds.) Facing the challenge of soybean rust in South America. JIRCAS, Tsukuba, p. 94-98 (JIRCAS working report no. 58).

Lemos NG, Braccini AL, Abdelnoor RV, Oliveira MCN, Suenaga K and Yamanaka N (2011) Characterization of genes Rpp2, Rpp4, and Rpp5 for resistance to soybean rust. Euphytica 182: 53-64.

Li S, Smith JR, Ray JD and Frederick RD (2012) Identification of a new soybean rust resistance gene in PI 567102B. Theoretical and Applied Genetics 125: 133-142.

Monteros MJ, Ha B-K, Phillips DV and Boerma HR (2010) SNP assay to detect the 'Hyuuga' red-brown lesion resistance gene for Asian soybean rust. Theoretical Applied Genetics 121: 1023-1032.

Oliveira ACB, Godoy CV and Martins MC (2005) Avaliação da tolerância de cultivares de soja à ferrugem asiática no Oeste da Bahia. Fitopatologia Brasileira 30: 658-662.

Pierozzi PHB, Ribeiro AS, Moreira JUV, Laperuta LDC, Rachid BF, Lima WF, Arias CAR, Oliveira MF and Toledo JFF (2008) New soybean (Glycine max Fabales, Fabaceae) sources of qualitative genetic resistance to Asian soybean rust caused by Phakopsora pachyrhizi (Uredinales, Phakopsoraceae). Genetics and Molecular Biology 31: 505-511.

Ray JD, Morel W, Smith JR, Frederik RD and Miles MR (2009) Genetics and mapping of adult plant rust resistance in soybean PI 587886 and PI 587880A. Theoretical and Applied Genetics 119: 271-280.

Saghai Maroof MA, Jeong SC, Gunduz I, Tucker DM, Buss GR and Tolin SA (2008) Pyramiding of soybean mosaic virus resistance genes by marker-assisted selection. Crop Science 48:517-526.

Silva DCG, Yamanaka N, Brogin RL, Arias CAA, Nepomuceno AL, Di Mauro AO, Pereira SS, Nogueira LM, Passianotto ALL and Abdelnoor RV (2008) Molecular mapping of two loci that confer resistance to Asian rust in soybean. Theoretical and Applied Genetics 117: 57-63.

Soares RM, Akamatsu H, Yamanaka N, Suenaga K, Yamaoka Y, Ivancovich A, Morel W and Janegitz T (2009) Variabilidade patogênica do fungo Phakopsora pachyrhizi. Parte I - projeto ferrugem da soja JIRCAS/ Embrapa Soja/CRIA/INTA/Tsukuba University. In Godoy CV, Seixas CDS and Soares RM (eds.) Reunião do consórcio antiferrugem safra 2008/2009. Embrapa Soja, Londrina, p. 93-101 (Embrapa Soja Documentos 315).

Twizeyimana M, Ojiambo PS, Ikotun T, Paul C, Hartman GL and Bandyopadhyay R (2007) Comparison of field, greenhouse, and detached-leaf evaluations of soybean germplasm for resistance to Phakopsora pachyrhizi. Plant Disease 91: 1161-1169.

Yamanaka N, Silva DCG, Passianotto AL, Nogueira LM, Polizel AM, Pereira SS, Santos JVM, Brogin RL, Arias CAA, Hoffmann-Campo CB, Nepomuceno AL and Abdelnoor RV (2008) Identification of DNA markers and characterization of the genes for resistance against Asian soybean rust. In Kudo H, Suenaga K, Soares RM and Toledo A (eds.) Facing the challenge of soybean rust in South America. JIRCAS, Tsukuba, p. 99-107 (JIRCAS working report no. 58).

Yamanaka N, Yamaoka Y, Kato M, Lemos NG, Passianotto ALL, Santos JVM, Benitez ER, Abdelnoor RV, Soares RM and Suenaga K (2010) Development of classification criteria for resistance to soybean rust and differences in virulence among Japanese and Brazilian rust populations. Tropical Plant Pathology 35: 153-162.

Yamanaka N, Lemos NG, Akamatsu H, Yamaoka Y, Silva DCG, Passianotto ALL, Abdelnoor RV, Soares RM and Suenaga K (2011) Soybean breeding materials useful for resistance to soybean rust in Brazil. Japan Agricultural Research Quarterly 45: 385-395.

Yamaoka Y, Fujiwara Y, Kakishima M, Katsuya K, Yamada K and Hagiwara H (2002) Pathogenic races of Phakopsora pachyrhizi on soybean and wild host plants collected in Japan. Journal of General Plant Pathology 68: 52-56.

Yorinori JT, Paiva WM, Frederick RD, Costamilan LM, Bertagnolli PF, Hartman GE, Godoy C V and Nunes J Jr (2005) Epidemics of Soybean Rust (Phakopsora pachyrhizi) in Brazil and Paraguay from 2001 to 2003. Plant Disease 89: 675-677.

Yorinori JT (2008) Soybean germplasms with resistance and tolerance to Asian rust and screening methods. In Kudo H, Suenaga K, Soares RM and Toledo A (eds.) Facing the challenge of soybean rust in South America. JIRCAS, Tsukuba, p. 70-87 (JIRCAS working report no. 58).

Zambenedetti EB, Alves E, Pozza EA, Araújo DV and Godoy CV (2007) Avaliação de parâmetros monocíclicos e da intensidade da ferrugem asiática (Phakopsora pachyrhizi) em diferentes genótipos de soja e posições de copa. Summa Phytopathologica 33: 178-181. 